\title{
Body Mass Index Changes during Pregnancy and Perinatal Outcomes - A Cross-Sectional Study
}

\section{Mudanças do índice de massa corporal na gravidez $e$ resultados perinatais - um estudo transversal}

\author{
Sirlei Siani Morais ${ }^{1}$ Simony Lira Nascimento ${ }^{2}$ Ana Carolina Godoy-Miranda ${ }^{1}$ Karina Tamy Kasawara ${ }^{1}$ \\ Fernanda Garanhani Surita ${ }^{1}$ \\ ${ }^{1}$ Universidade Estadual de Campinas (UNICAMP), \\ Campinas, SP, Brazil \\ 2 Universidade Federal do Ceará, Fortaleza, CE, Brazil \\ Address for correspondence Fernanda Garanhani Surita, Associate \\ Professor, Alexander Fleming 101, 13083-881, Campinas, SP, Brazil \\ (e-mail: surita@unicamp.br).
}

Rev Bras Ginecol Obstet 2018;40:11-19.

\begin{abstract}
Keywords

- pregnancy

- weight gain

- Atalah curve

- obesity

- cesarean-section

- fetal weight
\end{abstract}

\section{Resumo}

Objective To evaluate the relation between changes the body mass index (BMI) percentile, reflected in the Atalah curve, and perinatal outcomes.

Methods A cross-sectional study with 1,279 women was performed. Data regarding gestational weight, sociodemographic characteristics and perinatal outcomes were collected through medical charts, prenatal card and interviews in the postpartum period. Women could be classified according to the Atalah curve in the following categories: low weight, adequate weight, overweight, and obese. The BMI was calculated at the first and at the last prenatal care visits, and these values were compared.

Results An increase in the BMI category according to the Atalah classification occurred in $19.9 \%$ of pregnant women, and an increase of 3.4, 5.8 and 6.4 points of $\mathrm{BMI}$ were found for women respectively classified in the adequate weight, overweight and obese categories at the first prenatal visit. Women with high school education presented a lower chance of increasing their BMI (odds ratio [OR] 0:47 [0.24- 0.95]). Women who evolved with an increase in the the Atalah classification were associated with cesarean section (OR 1.97-2.28), fetal macrosomia (OR 4.13-12.54) and large for gestational age newborn (OR 2.88-9.83).

Conclusion Pregnant women who gained enough weight to move up in their BMI classification according to the Atalah curve had a higher chance of cesarean section and macrosomia. Women classified as obese, according to the Atalah curve, at the first prenatal visit had a high chance of cesarean section and delivering a large for gestational age newborn.

Objetivo Avaliar a relação entre mudanças no percentual do índice de massa corporal (IMC), refletidas na curva de Atalah, e resultados perinatais.

Métodos Foi realizado um estudo transversal com 1.279 mulheres. Os dados sobre o peso na gestação, características sociodemográficas e resultados perinatais foram received

August 11, 2017

accepted

October 17, 2017

published online

December 18, 2017
DOI https://doi.org/

10.1055/s-0037-1608885. ISSN 0100-7203.
Copyright (e 2018 by Thieme Revinter

Publicações Ltda, Rio de Janeiro, Brazil
License terms

(c) (1) $\ominus$ (\$) 


\section{Palavras-chave}

- gravidez

- ganho de peso

- curva de Atalah

- obesidade

- cesariana

- peso fetal coletados através de prontuários, cartão pré-natal e entrevistas no pós-parto. As mulheres foram classificadas de acordo com a curva de Atalah nas seguintes categorias: baixo peso, peso adequado, sobrepeso e obesidade. O IMC foi calculado na primeira e na última visita ao pré-natal e esses valores foram comparados.

Resultados Houve aumento na categoria do IMC segundo a classificação de Atalah em $19,9 \%$ das mulheres grávidas e um aumento de 3,4; 5,8 e 6,4 pontos do IMC foram encontrados para mulheres respectivamente classificadas nas categorias peso adequado, sobrepeso e obesidade na primeira consulta pré-natal. As mulheres com educação secundária apresentaram menor chance de aumentar sua classificação de IMC (odds ratio [OR] 0:47 [0,24-0,95]). As mulheres que evoluíram com o aumento na classificação de Atalah foram associadas a cesariana (OR 1,97-2,28), macrossomia fetal (OR 4,13-12,54) e recém-nascido grande para a idade gestacional (OR 2,88-9,83).

Conclusão Gestantes com ganho de peso excessivo, o suficiente para aumentar sua classificação do IMC segundo a curva de Atalah, tiveram maiores chances de cesariana e macrossomia. As mulheres classificadas como obesas na primeira visita pré-natal, de acordo com a curva de Atalah, tiveram uma grande chance de cesariana e recémnascido grande para a idade gestacional.

\section{Introduction}

Gestational weight gain (GWG) is a hot topic due to the increase in the prevalence of adverse maternal and neonatal outcomes. $^{1-5}$ Some studies have shown the relation between excessive GWG and maternal gestational diabetes; hypertensive disorders, including preeclampsia; postpartum depression; preterm delivery; congenital defects; fetal macrosomia; low newborn weight, and a long-term effect on child obesity. ${ }^{3,5-10}$

There is no pattern for nutritional recommendations during pregnancy. The information is different according to the country studied. ${ }^{11}$ All recommendations are based on the pre-gestational weight, body mass index (BMI) or curves that evaluate the distribution of weight gain during pregnancy. In Latin America, some countries use the Atalah curve as a reference to assess the nutritional status of pregnant women, based on their BMI (Additional file 1). ${ }^{12}$ This curve is a tool based on the intersection of BMI at the beginning of prenatal care - which can be early or late - with gestational age.

The use of the BMI facilitates the understanding of nutritional assessment during pregnancy and has already been adopted by the World Health Organization, ${ }^{1}$ has good association with the degree of adiposity and the risk of non-communicable chronic diseases, it is easy to calculate and has the advantage of not requiring a reference standard. ${ }^{12-15}$

During pregnancy, an increase on maternal weight gain is expected; however, according to the Atalah curve, the classification is presented as excessive or insufficient GWG. When these changes occur, special health attention is required during prenatal assistance.

The aim of this study was to evaluate the intrapregnancy BMI evolution, according to a reference curve used in Latin America (Atalah curve), and its association with perinatal outcomes.

\section{Methods}

This is an observational study with a secondary data analysis conducted based in an original cross-sectional study regarding GWG during pregnancy. This study was performed in three major hospitals in the city of Campinas, São Paulo, in the southeast of Brazil. Data collection was performed from October of 2011 to February of 2014. Potential participants were selected between 12 and 72 hours in the postpartum period. Eligibility criteria were postpartum women who lived in Campinas and had a birth at the hospital, singleton pregnancy and live newborn. Women who presented difficulty with written or verbal comprehension or had physical or psychological conditions that could interfere with comprehension and/or autonomy in the consent to participate were excluded. ${ }^{16}$

The eligible participants were identified through a standardized medical chart. They were invited to participate in this study and signed a consent form. This study protocol received approval from the Ethical Committee of the institution under registration number 991/2011.

\section{Target Population}

Campinas is the third most populous city in state of São Paulo, with $\sim 1.5$ million inhabitants and a mean of 15,000 deliveries per year. The sample size was based on the number of deliveries per year (single pregnancy) among Campinas residents, estimated at 14,693 in $2010 .{ }^{17}$ For the sample size computation, the highest variability possible based on annual deliveries was calculated, resulting in $p=50 \%(0.5)$, with a level of significance of 5\%, sampling error of $3 \%$, and, finally, we got to the number of $n=995$. The sample was divided into three major maternities, which cover $85 \%$ of hospital births in the city, according to the proportions of annual deliveries. These maternities were funded by the public health care system, supplementary health system, or both. 
We excluded women who had home births, because in the Southern region of Brazil the number of home births corresponds to only $0.22 \%$ of the total. ${ }^{17}$ A sample larger than the minimum necessary was recruited to protect against possible data loss.

\section{Data Collection}

Data collection was performed at each maternity ward on pre-specified days to ensure the required sample size. At the day of data collection, all eligible and available women on postpartum period were invited to participate in the study. Data for gestational period, co-morbidities, delivery, and newborn outcomes were collected from medical records and prenatal care cards. Those women who did not have the records of the weight values at the beginning of the pregnancy and before delivery were excluded, resulting in 1,110 pregnant women (-Fig. $\mathbf{1}$ ).

The BMI was calculated in two moments: at the first prenatal visit and at the last prenatal visit, and the women were classified according to gestational age and to the Latin American Atalahs reference curve, with its classifications of low weight, adequate weight, overweight, and obese.

Considering that women could be classified at two different times (at the beginning of prenatal care and at the last prenatal visit) and into four categories according to the Atalah curve, a total of 16 types of classification could occur. Hypothetically, we can consider a number for each class of BMI: 1 - for low weight, 2 - for adequate weight, 3 - for overweight and 4 - for obesity. A number was attributed to each woman (in accordance with the gestational age and the BMI category on the Atalah curve). The difference between these two BMIs (at the

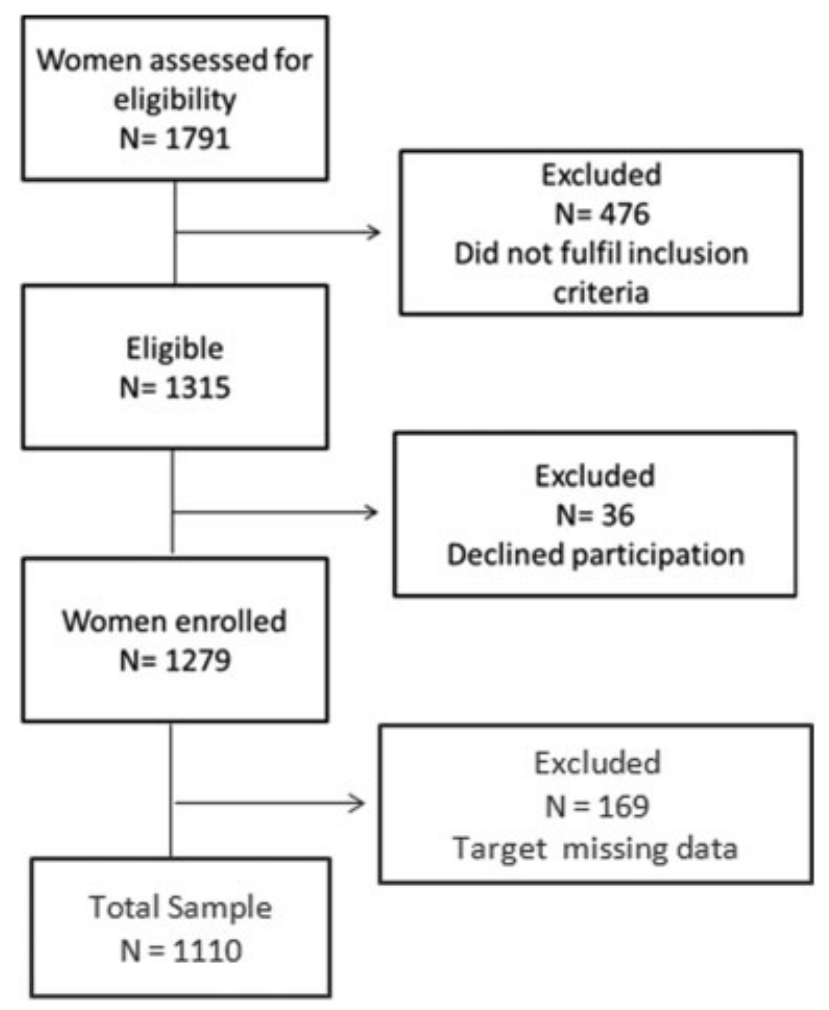

Fig. 1 Flowchart of participant selection for the study. beginning of pregnancy and at the last prenatal visit) was calculated. Those who presented no difference between the two measures were called stagnant in the curve, those with a positive difference we called increases in the curve (corresponding to an excessive gestational weight gain), and those with a negative difference were called decreased in the curve (insufficient gestational weight gain). In this sense, the two measures in the curve were evaluated in order to track each pregnant woman's BMI evolution.

\section{Statistical Analysis}

The evaluations were developed based on this classification in terms of the increased direction of the classes: low weight, adequate weigh, overweight and obesity. Among 1,110 women, 107 had a decrease in the curve. To estimate the risks, we considered only the women who had increased or remained stagnant in the curve. The quantitative variables were categorized following the values found in the literature. ${ }^{3,10,18}$ To analyze some variables related to the increases in the curve, we used the odds ratio (OR), with a corresponding 95\% confident interval $(\mathrm{CI})$. The multivariate analysis was performed using logistic regression with stepwise criteria for variables selection. The significance level was set at $5 \%$.

All the items in the strengthening the reporting of observational studies in epidemiology (STROBE) statement for an observational study were present in this paper. ${ }^{19}$

\section{Results}

The average age of women included in this study was $27.1 \pm 6.4$ years old, the majority of them had a partner (93.8\%) and claimed to not smoke during the pregnancy (92.3\%), half of them planned the pregnancy (49.7\%), was employed (54.1\%) and were white skin color (47.6\%).

At the first prenatal visit, the average of gestational age was $12.5 \pm 5.8$ weeks, and the BMI was $24.6 \pm 5.00 \mathrm{~kg} / \mathrm{m}^{2}$. Also, $9.6 \%$ of the women presented hypertensive disorders and $5.5 \%$ had pre-gestational or gestational diabetes (data not show).

A total of 221 women (19.9\%) with increased BMI according to the Atalah classification was found. There was an increase in the BMI throughout pregnancy in 74 women with initial overweight, 110 women with initial adequate weight and 37 women with initial low weight (-Table 1 ).

All obese women who gained weight moderately or excessively remained in the same classification, due to the limitation of this method, because there is no upper limit. In those obese women there was an increase in BMI from $35.2 \pm 4.2 \mathrm{~kg} / \mathrm{m}^{2}$ to $38.6 \pm 4.2 \mathrm{~kg} / \mathrm{m}^{2}$ between the first and the last prenatal visit ( - Table $\mathbf{1}$ ).

Among the pregnant women whose BMI had been previously classified as adequate, $22.5 \%$ became overweight (mean of BMI: $24.0 \pm 1.1 \mathrm{~kg} / \mathrm{m}^{2}$ at the first to $30.4 \pm 1.1 \mathrm{~kg} / \mathrm{m}^{2}$ at the last prenatal visit) and $0.4 \%$ (two women) became obese (-Table 1). Likewise, $23.9 \%$ of the pregnant women previously classified as overweight had become obese by the last prenatal visit (average of BMI at the first visit $28.7 \pm 1.2 \mathrm{~kg} / \mathrm{m}^{2}$ evolved to $34.5 \pm 1.3 \mathrm{~kg} / \mathrm{m}^{2}$ at the last prenatal visit) (-Table $\mathbf{1}$ ). 
14 Body Mass Index Changes during Pregnancy and Perinatal Outcomes Morais et al.

Table 1 Change in the BMI classification, according to the Atalah curve, between the first and the last prenatal visit

\begin{tabular}{|c|c|c|c|c|c|c|c|c|c|c|c|c|c|c|c|}
\hline \multirow{2}{*}{\multicolumn{2}{|c|}{$\begin{array}{l}\text { Classification according } \\
\text { to the Atalah curve (BMI) }\end{array}$}} & \multirow[b]{3}{*}{$n$} & \multirow[b]{3}{*}{$\%$} & \multicolumn{4}{|c|}{ First prenatal visit } & \multicolumn{4}{|c|}{ Last prenatal visit } & \multicolumn{4}{|c|}{ Gestational weight gain } \\
\hline & & & & \multicolumn{2}{|c|}{$\begin{array}{l}\text { BMI } \\
\left(\mathrm{kg} / \mathrm{m}^{2}\right)\end{array}$} & \multicolumn{2}{|c|}{$\begin{array}{l}\text { Weight } \\
\text { (kg) }\end{array}$} & \multicolumn{2}{|c|}{$\begin{array}{l}\text { BMI } \\
\left.\left(\mathrm{kg} / \mathrm{m}^{2}\right)\right)\end{array}$} & \multicolumn{2}{|c|}{$\begin{array}{l}\text { Weight } \\
\text { (kg) }\end{array}$} & \multicolumn{2}{|c|}{ BMI (\%) } & \multicolumn{2}{|c|}{ Weight (kg) } \\
\hline $\begin{array}{l}\text { First } \\
\text { prenatal } \\
\text { visit }\end{array}$ & $\begin{array}{l}\text { Last } \\
\text { prenatal } \\
\text { visit }\end{array}$ & & & mean & SD & mean & SD & mean & SD & mean & SD & mean & SD & mean & SD \\
\hline \multirow[t]{2}{*}{ Low weight } & Low weight & 129 & $77.7 \%$ & 18.9 & 2.1 & 51.0 & 7.0 & 22.7 & 1.5 & 61.2 & 6.3 & 29.0 & 105.5 & 10.2 & 5.0 \\
\hline & Adequate & 37 & $22.3 \%$ & 20.1 & 1.0 & 52.4 & 5.8 & 26.0 & 1.1 & 67.6 & 7.3 & 29.3 & 7.4 & 15.2 & 4.0 \\
\hline \multirow{4}{*}{$\begin{array}{l}\text { Adequate } \\
\text { Weight }\end{array}$} & Low weight & 44 & $9.2 \%$ & 22.2 & 1.2 & 59.6 & 6.5 & 24.0 & 0.8 & 64.5 & 6.9 & 8.5 & 6.5 & 4.9 & 3.7 \\
\hline & Adequate & 325 & $67.8 \%$ & 23.2 & 1.5 & 61.0 & 6.4 & 27.2 & 1.1 & 71.6 & 6.3 & 17.7 & 7.0 & 10.6 & 3.9 \\
\hline & Overweight & 108 & $22.5 \%$ & 24.0 & 1.1 & 61.8 & 6.1 & 30.4 & 1.1 & 78.1 & 6.5 & 26.7 & 7.1 & 16.3 & 3.7 \\
\hline & Obesity & 2 & $0.4 \%$ & 24.2 & 1.2 & 60.8 & 4.6 & 33.9 & 0.2 & 85.3 & 1.8 & 40.6 & 7.7 & 24.5 & 2.8 \\
\hline \multirow[t]{3}{*}{ Overweight } & Adequate & 49 & $15.8 \%$ & 26.4 & 1.0 & 70.4 & 6.8 & 28.1 & 0.9 & 74.8 & 6.9 & 6.4 & 5.4 & 4.4 & 3.7 \\
\hline & Overweight & 187 & $60.3 \%$ & 27.4 & 1.4 & 71.6 & 6.9 & 31.1 & 1.2 & 81.0 & 6.9 & 13.5 & 6.2 & 9.5 & 4.1 \\
\hline & Obesity & 74 & $23.9 \%$ & 28.7 & 1.2 & 75.4 & 7.8 & 34.5 & 1.3 & 90.7 & 8.9 & 20.5 & 6.5 & 15.3 & 4.5 \\
\hline \multirow[t]{3}{*}{ Obesity } & Adequate & 1 & $0.6 \%$ & 30.1 & - & 79.0 & - & 28.0 & - & 73.4 & - & -7.1 & - & -5.6 & - \\
\hline & Overweight & 13 & $8.4 \%$ & 31.4 & 0.9 & 82.9 & 8.8 & 32.3 & 0.7 & 85.1 & 7.7 & 2.8 & 3.6 & 2.2 & 3.0 \\
\hline & Obesity & 141 & $91.0 \%$ & 35.2 & 4.2 & 91.7 & 12.8 & 38.6 & 4.2 & 100.6 & 12.7 & 10.0 & 6.3 & 8.9 & 5.5 \\
\hline
\end{tabular}

Abbreviations: BMI, body mass index; SD, standard deviation.

An average increase of 6.4 points in BMI occurred among women whose BMI had been previously classified as adequate and who presented overweight in the last measurement. The women previously classified as overweight who became obese presented an increase of 5.8 points in BMI, and the obese women presented an average increase of 3.4 points (-Table 1).

The analysis of the sociodemographic factors found that only the education level associated with an increase of BMI classification in the curve: women with only elementary school education, and those with graduation had a greater chance of increasing their classification in the curve than those women with high school education (OR $2.11 \mathrm{CI}$ : 1.05-4.25 and OR 1.80 CI: $1.02-3.17$ respectively)(-Table 2 ). Likewise, on the multivariate analysis using logistic regression with stepwise criteria for variables selection, the education level was the only variable selected, resulting in the same OR (data not shown).

The association between initial BMI and pregnancy outcome showed that women who were classified as obese at the initial prenatal visit had a higher chance of delivering by cesarean section (OR: $2.35 \mathrm{CI}$ : $1.60-3.44)$ and having large for gestational age (LGA) newborns (OR $2.86 \mathrm{CI}$ : 1.36-6.01) (-Table 3).

Regarding neonatal outcomes, women who increased their classification of BMI according to the Atalah curve had a higher chance [2.88 (1.55-5.38)] of having a newborn LGA than those who did not present any change in their BMI (stagnant group) (-Table 4 ).

Also, women whose BMI was first classified as adequate and who evolved with an increase in their classification in the curve at the last prenatal visit had a higher chance of delivering by cesarean section (OR 1.97 (1.25-3.10), fetal macrosomia (OR 4.13(1.50-11.40) and LGA newborns (OR 3.06 [1.19 to 7.87$]$ ) (-Table 4 ).
In the same way, those women first classified as overweight who increased in the curve had a higher chance of delivering by cesarean section - OR 2.28 (1.26-4.14), fetal macrosomia- OR 12.54 (2.64-59.67) and LGA babies- OR 9.83 (2.61 to 36.94) than women with stagnant classification (overweight throughout the entire prenatal period) (- Table 4).

There is no possibility of increase in the BMI classification for obese women because in the Atalah curve there is no classification after obese. Therefore, $91 \%$ of the obese women remained in the same classification and only 14 women (9\%) had a decrease in their BMI classification and moved down to the overweight or adequate weight category. Even for those women who started the prenatal in the obese category ( - Table 1), the ORs were not significant (data not shown).

\section{Discussion}

Our results showed an association between the increase in the BMI classification during pregnancy, according to the Atalah curve and cesarean delivery, LGA newborns and fetal macrosomia. Furthermore, women classified as obese in the first prenatal visit also had a higher chance of giving birth by cesarean section and their newborns were classified as LGA.

Other studies that address women from other ethnicities, cultures and countries also found similar results. It is widely discussed what factor would be associated with the worst prognosis for perinatal outcomes: maternal obesity or excessive weight gain during pregnancy. Currently, the trend is that both interfere negatively in perinatal outcomes. ${ }^{9,20-22}$

Although most women maintained their BMI classification according to the Atalah curve (stagnant in the curve), around $20 \%$ of them gained weight excessively, enough to move into the next category in the curve, and this fact is 
Table 2 Association between sociodemographics characteriscs and BMI evolution according to the Atalah curve during prenatal care

\begin{tabular}{|c|c|c|c|c|c|c|c|c|c|c|c|c|c|}
\hline \multirow[t]{3}{*}{ Variables } & \multicolumn{5}{|c|}{ All women } & \multicolumn{4}{|c|}{$\begin{array}{l}\text { Women with adequate } \mathrm{BMI} \text { in the } \\
\text { first prenatal visit }\end{array}$} & \multicolumn{4}{|c|}{$\begin{array}{l}\text { Women with overweight } \mathrm{BMI} \text { in the } \\
\text { last prenatal visit }\end{array}$} \\
\hline & \multirow{2}{*}{$\begin{array}{l}\text { Stag } \\
n\end{array}$} & \multirow{2}{*}{$\begin{array}{l}\text { Incr } \\
\mathrm{n} \\
\end{array}$} & \multirow{2}{*}{\multicolumn{3}{|c|}{$\begin{array}{l}\text { OR } \\
\text { (CI 95\%)* }\end{array}$}} & Stag & Incr & \multirow{2}{*}{\multicolumn{2}{|c|}{$\begin{array}{l}\text { OR } \\
\text { (Cl 95\%)* }\end{array}$}} & Stag & Incr & \multirow{2}{*}{\multicolumn{2}{|c|}{$\begin{array}{l}\text { OR } \\
(\mathrm{Cl} 95 \%)^{*}\end{array}$}} \\
\hline & & & & & & $\mathrm{n}$ & $\mathrm{n}$ & & & $\mathrm{n}$ & $\mathrm{n}$ & & \\
\hline \multicolumn{14}{|l|}{ Age } \\
\hline$\leq 19$ & 99 & 36 & 0.74 & $\begin{array}{l}(0.48- \\
1.12)\end{array}$ & & 46 & 18 & 0.86 & $\begin{array}{l}(0.47- \\
1.58)\end{array}$ & 15 & 6 & 0.96 & $(0.35-2.61)$ \\
\hline $20-34$ & 574 & 154 & Ref & & & 231 & 78 & Ref & & 138 & 53 & Ref & \\
\hline $35-39$ & 89 & 25 & 0.96 & $\begin{array}{l}(0.59- \\
1.54)\end{array}$ & & 40 & 11 & 1.23 & $\begin{array}{l}(0.60- \\
2.51)\end{array}$ & 27 & 13 & 0.80 & $(0.38-1.66)$ \\
\hline$\geq 40$ & 20 & 6 & 0.89 & $\begin{array}{l}(0.35- \\
2.27) \\
\end{array}$ & & 8 & 3 & 0.90 & $\begin{array}{l}(0.23- \\
3.48) \\
\end{array}$ & 7 & 2 & 1.24 & $(0.27-6.68)$ \\
\hline \multicolumn{14}{|l|}{ Ethnicity } \\
\hline White & 375 & 116 & \multicolumn{3}{|l|}{ Ref } & 163 & 58 & \multicolumn{2}{|l|}{ Ref } & 88 & 42 & \multicolumn{2}{|l|}{ Ref } \\
\hline Non-White & 405 & 104 & 1.20 & $\begin{array}{l}(0.89- \\
1.63)\end{array}$ & & 161 & 51 & 1.12 & $\begin{array}{l}(0.73- \\
1.73) \\
\end{array}$ & 99 & 32 & 1.48 & $(0.86-2.54)$ \\
\hline \multicolumn{14}{|c|}{ Education Level } \\
\hline $\begin{array}{l}\text { Elementary } \\
\text { School }\end{array}$ & 157 & 41 & 1.151 .15 & $\begin{array}{l}(0.777 \\
1.70)\end{array}$ & & 55 & 11 & 2.11 & $\begin{array}{l}(1.058- \\
4.25)\end{array}$ & 46 & 19 & 0.87 & $(0.45-1.69)$ \\
\hline High School & 448 & 134 & Ref & & & 187 & 79 & Ref & & 97 & 35 & Ref & \\
\hline Graduation & 175 & 44 & 1.19 & $\begin{array}{l}(0.81- \\
1.74) \\
\end{array}$ & & 81 & 19 & 1.80 & $\begin{array}{l}(1.02- \\
3.17) \\
\end{array}$ & 44 & 19 & 0.84 & $(0.43-1.62)$ \\
\hline \multicolumn{14}{|l|}{ Parity } \\
\hline Primiparous & 366 & 122 & Ref & 160 & 59 & Ref & 72 & 32 & Ref & & & & \\
\hline Multiparous & 416 & 99 & 1.40 & $\begin{array}{l}(1.04- \\
1.89)\end{array}$ & & 165 & 51 & 1.19 & $\begin{array}{l}(0.77- \\
1.84)\end{array}$ & 115 & 42 & 1.22 & $(0.70-2.10)$ \\
\hline \multicolumn{14}{|c|}{ Hypertension } \\
\hline No & 704 & 201 & \multicolumn{3}{|l|}{ Ref } & 307 & 101 & \multicolumn{2}{|l|}{ Ref } & 169 & 65 & \multicolumn{2}{|l|}{ Ref } \\
\hline Yes & 77 & 20 & 1.10 & $\begin{array}{l}(0.66- \\
1.84)\end{array}$ & & 18 & 9 & 0.66 & $\begin{array}{l}(0.29- \\
1.51)\end{array}$ & 17 & 9 & 0.73 & $(0.31-1.71)$ \\
\hline \multicolumn{14}{|l|}{ Diabetes } \\
\hline No & 733 & 213 & \multicolumn{3}{|l|}{ Ref } & 316 & 109 & \multicolumn{2}{|l|}{ Ref } & 175 & 67 & \multicolumn{2}{|l|}{ Ref } \\
\hline Yes & 47 & 7 & 1.95 & $\begin{array}{l}(0.87- \\
4.38) \\
\end{array}$ & & 9 & 1 & 3.10 & $\begin{array}{l}(0.39- \\
24.79) \\
\end{array}$ & 10 & 6 & 0.64 & $(0.22-1.82)$ \\
\hline \multicolumn{14}{|c|}{ Planned pregnancy } \\
\hline Yes & 391 & 112 & \multicolumn{3}{|l|}{ Ref } & 170 & 59 & Ref & & 94 & 41 & Ref & \\
\hline No & 391 & 108 & 1.04 & $\begin{array}{l}(0.77- \\
1.40)\end{array}$ & & 155 & 50 & 1.08 & $\begin{array}{l}(0.70- \\
1.66) \\
\end{array}$ & 93 & 33 & 1.23 & $(0.72-2.11)$ \\
\hline Smoking & & & & & & & & & & & & & \\
\hline No & 725 & 208 & Ref & & & 303 & 105 & Ref & & 168 & 70 & Ref & \\
\hline Yes & 56 & 13 & 1.24 & $\begin{array}{l}(0.66- \\
2.30)\end{array}$ & & 22 & 5 & 1.52 & $\begin{array}{l}(0.56- \\
4.13)\end{array}$ & 18 & 4 & 1.88 & $(0.61-5.74)$ \\
\hline Health insur & & & & & & & & & & & & & \\
\hline Private & 248 & 71 & Ref & & & 115 & 34 & Ref & & 57 & 26 & Ref & \\
\hline Public & 532 & 149 & 1.02 & & & $(0.74-$ & 1.41) & 209 & & 75 & 0.82 & $(0.52$ & .17) \\
\hline
\end{tabular}

Abbreviations: BMI, body mass index; $\mathrm{Cl}$, confidence interval; Incr, increased; OR, odds ratio; ref, reference level; Stag, stagnant. * chance of increase in the Atalah curve.

important mainly because this change was associated with adverse perinatal outcomes.

Overweight women were those who presented the most significant change in BMI classification, which meant to move into the obesity category. This fact, in addition to the impact on the current pregnancy, increases the risk of weight retention in the postpartum period and consequently the long-term risks caused by obesity and related comorbidities. 3,6,23

Also, overweight women get more beneficial effects of interventions such as physical activity and nutritional 
Table 3 Association between the mode of delivery and neonatal outcomes according to the initial BMI classification in the Atalah curve at the first prenatal visit

\begin{tabular}{|c|c|c|c|c|c|c|c|}
\hline \multirow[t]{2}{*}{ Variables } & \multirow{2}{*}{$\begin{array}{l}\text { Low/Adequate } \\
\mathrm{n}\end{array}$} & \multirow{2}{*}{$\begin{array}{l}\text { Overweight } \\
\mathrm{n}\end{array}$} & \multirow{2}{*}{$\begin{array}{l}\text { Obesity } \\
\mathrm{n}\end{array}$} & \multicolumn{2}{|c|}{ OR - Overweight } & \multicolumn{2}{|c|}{ OR - Obesity } \\
\hline & & & & & & & \\
\hline \multicolumn{8}{|c|}{ Mode of delivery } \\
\hline missing data & 0 & 1 & 0 & & & & \\
\hline Vaginal & 300 & 127 & 43 & \multicolumn{2}{|l|}{ Ref } & \multicolumn{2}{|l|}{ Ref } \\
\hline C-section & 351 & 186 & 118 & 1.25 & $(0.95-1.65)$ & 2.35 & $(1.60-3.44)$ \\
\hline \multicolumn{8}{|c|}{ Gestational age at birth (weeks) } \\
\hline missing data & 6 & 3 & 6 & & & & \\
\hline$\geq 37$ & 612 & 299 & 143 & \multicolumn{2}{|l|}{ Ref } & \multicolumn{2}{|l|}{ Ref } \\
\hline$<37$ & 33 & 12 & 12 & 0.74 & $(0.38-1.46)$ & 1.56 & $(0.78-3.09)$ \\
\hline \multicolumn{8}{|c|}{ Newborn weight (grs) } \\
\hline missing data & 7 & 7 & 5 & & & & \\
\hline$<2500$ & 43 & 14 & 9 & 0.67 & $(0.36-1.25)$ & 0.88 & $(0.42-1.85)$ \\
\hline $2500-3999$ & 584 & 282 & 139 & \multicolumn{2}{|l|}{ Ref } & \multicolumn{2}{|l|}{ Ref } \\
\hline$\geq 4000$ & 17 & 11 & 8 & 1.34 & $(0.62-2.90)$ & 1.98 & $(0.84-4.67)$ \\
\hline \multicolumn{8}{|c|}{ Somatic neonatal age (weeks) } \\
\hline missing data & 22 & 15 & 13 & & & & \\
\hline$\geq 37$ & 598 & 280 & 136 & \multicolumn{2}{|l|}{ Ref } & \multicolumn{2}{|l|}{ Ref } \\
\hline$<37$ & 31 & 19 & 12 & 1.31 & $(0.73-2.36)$ & 1.70 & $(0.85-3.40)$ \\
\hline \multicolumn{8}{|c|}{ APGAR on the 1 st minute } \\
\hline missing data & 11 & 6 & 5 & & & & \\
\hline$\geq 7$ & 613 & 292 & 147 & \multicolumn{2}{|l|}{ Ref } & \multicolumn{2}{|l|}{ Ref } \\
\hline$<7$ & 27 & 16 & 9 & 1.24 & $(0.66-2.34)$ & 1.39 & $(0.64-3.02)$ \\
\hline \multicolumn{8}{|c|}{ APGAR on the 5 th minute } \\
\hline missing data & 2 & 1 & 0 & & & & \\
\hline$\geq 7$ & 649 & 312 & 161 & \multicolumn{2}{|l|}{ Ref } & \multicolumn{2}{|l|}{ Ref } \\
\hline$<7$ & 0 & 1 & 0 & 6.24 & $(0.25-153.50)$ & 4.02 & $(0.08-203.46)$ \\
\hline \multicolumn{8}{|c|}{ Newborn weight adequacy } \\
\hline missing data & 13 & 10 & 11 & & & & \\
\hline SGA & 77 & 18 & 10 & 0.47 & $(0.27-0.80)$ & 0.55 & $(0.28-1.07)$ \\
\hline AGA & 543 & 272 & 128 & \multicolumn{2}{|l|}{ Ref } & \multicolumn{2}{|l|}{ Ref } \\
\hline LGA & 18 & 14 & 12 & 1.56 & $(0.77-3.16)$ & 2.86 & $(1.36-6.01)$ \\
\hline
\end{tabular}

Abbreviations: AGA, adequate for gestational age; Cl, confidence interval; LGA, large for gestational age; OR, odds ratio; ref, reference group; SGA, small for gestational age.

counseling, compared with obese women, to achieve adequate weight during prenatal care. ${ }^{24-26}$ Thus, overweight women are those who are "on the edge," and the actions of the health care team as well as their personal motivations can be decisive for them to change their habits and consequently, their future risk. ${ }^{7,24}$

The increase in the BMI category classification during pregnancy or excessive GWG presented the most striking results in overweight women, such as the chance of having a LGA child. This fact should alert healthcare teams to be more attentive when laying out their recommendations to overweight women. ${ }^{27,28}$
Obese women had obvious maternal and fetal risks, and health care teams and the women themselves pay closer attention to the weight increment. It might be a reason for some results being less significant in the obese group. However, pre-pregnancy obesity, regardless of GWG, increased the chance of caesarean section, macrosomia and LGA. ${ }^{29,30}$

In this context, data from this study point to the need for guidance in all pre-pregnancy BMI categories, and specially for pregnant women with overweight. ${ }^{31}$

These results show total weight gain throughout the pregnancy. Currently, there is a concern with determining in which of the stages of pregnancy excessive weight gain 
Table 4 Association between the mode of delivery and neonatal outcomes according to the evolution of BMI in the Atalah classification during prenatal care

\begin{tabular}{|c|c|c|c|c|c|c|c|c|c|c|c|c|}
\hline \multirow[t]{3}{*}{ Outcomes } & \multicolumn{4}{|c|}{ All Sample } & \multicolumn{4}{|c|}{$\begin{array}{l}\text { Women with adequate BMI in the } \\
\text { first prenatal visit }\end{array}$} & \multicolumn{4}{|c|}{$\begin{array}{l}\text { Women with overweight BMI in } \\
\text { the last prenatal visit }\end{array}$} \\
\hline & \multirow{2}{*}{$\begin{array}{l}\text { Stag } \\
n\end{array}$} & \multirow{2}{*}{$\begin{array}{l}\text { Incr } \\
n\end{array}$} & \multirow{2}{*}{\multicolumn{2}{|c|}{ OR (CI 95\%)* }} & \multirow{2}{*}{$\begin{array}{l}\text { Stag } \\
n\end{array}$} & \multirow{2}{*}{$\frac{\operatorname{lncr}}{n}$} & \multirow{2}{*}{\multicolumn{2}{|c|}{ OR (Cl 95\%)* }} & Stag & Incr & \multirow{2}{*}{\multicolumn{2}{|c|}{ OR (CI 95\%) }} \\
\hline & & & & & & & & & $n$ & $n$ & & \\
\hline \multicolumn{13}{|c|}{ Mode of delivery } \\
\hline Vaginal & 333 & 81 & \multicolumn{2}{|l|}{ Ref } & 148 & 43 & \multicolumn{2}{|l|}{ Ref } & 82 & 19 & \multicolumn{2}{|l|}{ Ref } \\
\hline C-section & 448 & 140 & 1.28 & $(0.94-1.75)$ & 117 & 67 & 1.97 & $(1.25-3.10)$ & 104 & 55 & 2.28 & $(1.26-4.14)$ \\
\hline \multicolumn{13}{|c|}{ Gestational age at birth } \\
\hline$\geq 37$ & 741 & 209 & \multicolumn{2}{|l|}{ ref } & 313 & 106 & \multicolumn{2}{|l|}{ Ref } & 179 & 71 & \multicolumn{2}{|l|}{ Ref } \\
\hline$<37$ & 41 & 12 & 1.04 & $(0.54-2.01)$ & 12 & 4 & 0.98 & $(0.31-3.12)$ & 8 & 3 & 0.95 & $(0.24-3.67)$ \\
\hline \multicolumn{13}{|c|}{ Newborn weight (g) } \\
\hline$<2,500$ & 49 & 11 & 0.84 & $(0.43-1.64)$ & 16 & 5 & 1.00 & $(0.36-2.82)$ & 10 & 3 & 0.84 & $(0.22-3.14)$ \\
\hline 2500-3999 & 702 & 188 & \multicolumn{2}{|l|}{ Ref } & 299 & 93 & \multicolumn{2}{|l|}{ Ref } & 170 & 61 & \multicolumn{2}{|l|}{ Ref } \\
\hline$\geq 4000$ & 49 & 18 & 1.37 & $(0.78-2.41)$ & 7 & 9 & 4.13 & $(1.50-11.40)$ & 2 & 9 & 12.54 & $(2.64-59.67)$ \\
\hline \multicolumn{13}{|c|}{ Somatic neonatal age (weeks) } \\
\hline$\geq 37$ & 704 & 200 & \multicolumn{2}{|l|}{ Ref } & 303 & 103 & \multicolumn{2}{|l|}{ Ref } & 165 & 67 & \multicolumn{2}{|l|}{ Ref } \\
\hline$<37$ & 43 & 14 & 1.15 & $(0.61-2.14)$ & 10 & 3 & 0.88 & $(0.24-3.27)$ & 12 & 6 & 1.23 & $(0.44-3.42)$ \\
\hline \multicolumn{13}{|c|}{ APGAR 1st minute } \\
\hline$\geq 7$ & 728 & 206 & \multicolumn{2}{|l|}{ Ref } & 307 & 101 & \multicolumn{2}{|l|}{ Ref } & 172 & 68 & Ref & \\
\hline$<7$ & 37 & 12 & 1.15 & $(0.59-2.24)$ & 10 & 7 & 2.13 & $(0.79-5.74)$ & 11 & 5 & 1.15 & $(0.39-3.43)$ \\
\hline APGAR 5th I & inute & & & & & & & & & & & \\
\hline$\geq 7$ & 779 & 221 & Ref & & 323 & 110 & Ref & & 155 & 74 & Ref & \\
\hline$<7$ & 1 & 0 & 1.17 & $(0.05-28.90)$ & 2 & 0 & 0.59 & $(0.03-12.29)$ & 1 & 0 & 0.70 & $(0.03-17.28)$ \\
\hline Newborn w & ight ac & equac) & & & & & & & & & & \\
\hline SGA & 74 & 14 & 0.69 & $(0.38-1.25)$ & 56 & 9 & 0.49 & $(0.20-2.77)$ & 8 & 5 & 1.84 & $(0.58-5.86)$ \\
\hline AGA & 670 & 184 & Ref & & 385 & 126 & Ref & & 171 & 58 & Ref & \\
\hline LGA & 24 & 19 & 2.88 & $(1.55-5.38)$ & 9 & 9 & 3.06 & $(1.19-7.87)$ & 3 & 10 & 9.83 & $(2.61-36.94)$ \\
\hline
\end{tabular}

Abbreviations: AGA, adequate for gestational age; $\mathrm{Cl}$, confidence interval; Incr, increased; LGA, large for gestational age; OR, odds ratio; ref, reference level; SGA, small for gestational age; Stag, stagnant.

occurs and whether this relates to higher risks to the fetus. It is believed that increased weight gain in the early stages of pregnancy is associated with an adverse cardio-metabolic profile in the offspring. ${ }^{7}$

In this stream of thought, epigenetic changes could mediate the association of pre-pregnancy maternal BMI and GWG with adverse outcomes. Different epigenetic mechanisms in the early development of the fetus could affect the susceptibility to several diseases in adulthood. However, there is a lack of knowledge in human studies and the specific association of GWG in early pregnancy and DNA methylation needs further exploration. Excessive GWG in early pregnancy may be associated with increased methylation in some genes in cord blood DNA. Also, attention must be drawn to the combined effects of functional nutrition and physical exercise as metabolic reprogramming tools to control maternal weight in an attempt to optimize the health of the mother and child. ${ }^{32,33}$
Fetal macrosomia is a factor that can increase the chance of obesity in childhood, thus keeping the vicious circle of obesity with all its consequences in the medium and long term. $^{34}$

Regarding the maternal outcomes, the increased chance of cesarean section in these groups of women goes in the opposite direction of the guidelines to increase the vaginal delivery rates, showing that it may be one of the modifiable factors in an attempt to increase the percentage of vaginal delivery. $^{35}$

The bivariate and multivariate analyses found education level as the only sociodemographic characteristic associated with the increase in BMI classification along the pregnancy. Women with high school education level showed the best results. The association of excessive weight gain with lower educational level has been found in other studies, drawing attention to the inequalities. ${ }^{31,36}$ 
It is difficult to standardize what is the ideal GWG for each population considering their ethnic and cultural variations. Although all guidelines have limitations, some guidance is always better than none. ${ }^{37}$

Even the Institute of Medicine (IOM), which is responsible for one of the most used guidelines, is continuously questioned and modified because the characteristics of pregnant women, as those of any other group of people, can suffer modifications through time. However, some standardization must be provided for professionals who work directly with these women. ${ }^{38}$

Having a standardization does not mean it will be followed, hence the importance of the orientation of the health care team, including psychological support and personal motivations. The multidisciplinary team working on women's health during the prenatal must consider that the weight gain during pregnancy, with all its positive and negative impacts, is a modifiable factor. ${ }^{39,40}$

There are limitations of the Atalah curve in relation to neonatal results, and for obese pregnant women the limitations are inherent in the evaluation method, which can influence the results because there is no upper limit on the curve. Pregnant women with adequate weight who are now overweight or obese, in turn, are easily identified as well as the overweight moving towards obesity; on the other hand, the obese women, even gaining weight, will remain in the same category, which cannot be accurately assessed in order for the health care professionals to provide adequate recommendations. The standardization of weight gain for obese women is still very controversial and more studies are needed to evaluate the same, but this is the method recommended by the ministry of health in Brazil. 2,6,8,41

Guidelines are extremely important to support the health care professionals group linked to pregnant women and newborns, but we must consider the difficulties inherent in the personal care that the mathematical curve does not absorb, such as personal motivations and psychological support. ${ }^{42,43}$

Weight gain during pregnancy may be reported incorrectly through no scientific information facility, another factor that shows the importance of specific knowledge of the information on prenatal care. ${ }^{44}$ Social norms and medical evidence differ on the appropriate gestational weight gain. Social factors, such as the belief that pregnant women are allowed to put on weight, lead women to believe that weight gain should not be limited during pregnancy, and many doctors still find it difficult to clarify the weight gain limits during the different times throughout the pregnancy, making standardization and knowledge still an issue to be explored. ${ }^{40}$

\section{Conclusion}

Women classified according to the Atalah curve as obese in the beginning of prenatal care had a higher chance of cesarean delivery and of having LGA newborns. Increase in the BMI classification according to Atalah curve is associated with macrosomia and cesarean delivery for women classified as overweight or adequate weight. Pregnant women with adequate weight who become overweight or obese, and over- weight women who became obese had a higher GWG than the obese in this population. Guidelines on GWG should be given to all pregnant women because they allow them to know that they are at risk of excessive weight gain and the adverse perinatal outcomes of such. In addition, excessive weight gain during pregnancy may compromise the long-term women's health as well as the health of their children, both for the future risk of obesity and comorbidities associated with it.

\section{Contributions}

The idea for the study and this specific analytical approach arose in a group discussion among Morais S. S., Surita F. G. and Nascimento S. L. Analyses were planned and performed by Morais S. S. and Surita F. G. The first version of the manuscript was drafted by Morais S. S. and then complemented with suggestions from all the others. Nascimento SL, GodoyMiranda AC and Kasawara K. T. contributed to the development of the study protocol and data collection. All authors read and approved the final version of the manuscript.

\section{Conflicts to Interest}

The authors have stated explicitly that there are no conflicts of interest in connection with this article.

\section{Acknowledgments}

We want to thank the $\mathrm{SAR}_{3} \mathrm{HAS}$ (Reproductive Health and Healthy Habits) Research Group for the valuable discussion regarding data analysis.

\section{References}

1 World Health Organization. Obsesity and Overweight. Geneva: WHO; 2013. (WHO Fact Sheet; no. 311). http://www.who.int/ mediacentre/factsheets/fs311/en/. Accessed June 10, 2016

2 Kapadia MZ, Park CK, Beyene J, Giglia L, Maxwell C, McDonald SD. Weight loss instead of weight gain within the guidelines in obese women during pregnancy: a systematic review and meta-analyses of maternal and infant outcomes. PLoS One 2015;10(07):e0132650

3 Villamor E, Cnattingius S. Interpregnancy weight change and risk of adverse pregnancy outcomes: a population-based study. Lancet 2006;368(9542):1164-1170

4 Forouzanfar MH, Alexander L, Anderson HR, et al; GBD 2013 Risk Factors Collaborators. Global, regional, and national comparative risk assessment of 79 behavioural, environmental and occupational, and metabolic risks or clusters of risks in 188 countries, 1990-2013: a systematic analysis for the Global Burden of Disease Study 2013. Lancet 2015;386(10010):2287-2323

5 Gaillard R, Felix JF, Duijts L, Jaddoe VW. Childhood consequences of maternal obesity and excessive weight gain during pregnancy. Acta Obstet Gynecol Scand 2014;93(11):1085-1089

6 Brunner S, Stecher L, Ziebarth S, et al. Excessive gestational weight gain prior to glucose screening and the risk of gestational diabetes: a meta-analysis. Diabetologia 2015;58(10):2229-2237

7 Gaillard R. Maternal obesity during pregnancy and cardiovascular development and disease in the offspring. Eur J Epidemiol 2015; 30(11):1141-1152

8 Bogaerts A, Ameye L, Martens E, Devlieger R. Weight loss in obese pregnant women and risk for adverse perinatal outcomes. Obstet Gynecol 2015;125(03):566-575

9 Marchi J, Berg M, Dencker A, Olander EK, Begley C. Risks associated with obesity in pregnancy, for the mother and baby: a systematic review of reviews. Obes Rev 2015;16(08):621-638 
10 Gaudet L, Ferraro ZM, Wen SW, Walker M. Maternal obesity and occurrence of fetal macrosomia: a systematic review and metaanalysis. BioMed Res Int 2014;2014:640291

11 Alavi N, Haley S, Chow K, McDonald SD. Comparison of national gestational weight gain guidelines and energy intake recommendations. Obes Rev 2013;14(01):68-85

12 Atalah E, Castillo C, Castro R, Aldea A. [Proposal of a new standard for the nutritional assessment of pregnant women]. Rev Med Chil 1997;125(12):1429-1436

13 Rosso P. Weight-for-heigh / body mass index in pregnant women. In: Krasovec K, Anderson MA, eds. Maternal Nutrition and Pregnancy Outcomes: Anthropometric Assessment. Washington, DC: PAHO; 1991:173-185. (Scientific Publication; no. 529)

14 Ministério da Saúde. Pré-Natal e Puerpério: Atenção Qualificada e Humanizada. $3^{a}$ ed. Brasília, DF: Ministério da Saúde; 2006. http:// bvsms.saude.gov.br/bvs/publicacoes/manual_pre_natal_puerperio_3ed.pdf. Acesso Maio 10, 2013

15 Mardones F, Rosso P. A weight gain chart for pregnant women designed in Chile. Matern Child Nutr 2005;1(02):77-90

16 Nascimento SL, Surita FG, Godoy AC, Kasawara KT, Morais SS. Physical activity patterns and factors related to exercise during pregnancy: a cross sectional study. PLoS One 2015;10(06): e0128953

17 Olson CM, Strawderman MS, Reed RG. Efficacy of an intervention to prevent excessive gestational weight gain. Am J Obstet Gynecol 2004;191(02):530-536

18 Birdsall KM, Vyas S, Khazaezadeh N, Oteng-Ntim E. Maternal obesity: a review of interventions. Int J Clin Pract 2009;63(03): 494-507

19 von Elm E, Altman DG, Egger M, Pocock SJ, Gøtzsche PC, Vandenbroucke JP; STROBE Initiative. The Strengthening the Reporting of Observational Studies in Epidemiology (STROBE) Statement: guidelines for reporting observational studies. Int J Surg 2014; 12(12):1495-1499

20 Li C, Liu Y, Zhang W. Joint and independent associations of gestational weight gain and pre-pregnancy body mass index with outcomes of pregnancy in chinese women: a retrospective cohort study. PLoS One 2015;10(08):e0136850

21 Haugen M, Brantsæter AL, Winkvist A, et al. Associations of prepregnancy body mass index and gestational weight gain with pregnancy outcome and postpartum weight retention: a prospective observational cohort study. BMC Pregnancy Childbirth 2014; $14: 201$

22 Dzakpasu S, Fahey J, Kirby RS, et al. Contribution of prepregnancy body mass index and gestational weight gain to caesarean birth in Canada. BMC Pregnancy Childbirth 2014;14:106

23 Biesmans K, Franck E, Ceulemans C, Jacquemyn Y, Van Bogaert P. Weight during the postpartum period: what can health care workers do? Matern Child Health J 2013;17(06):996-1004

24 Chasan-Taber L, Marcus BH, Rosal MC, et al. Proyecto Mamá: a lifestyle intervention in overweight and obese Hispanic women: a randomised controlled trial-study protocol. BMC Pregnancy Childbirth 2015;15:157

25 Nascimento SL, Pudwell J, Surita FG, Adamo KB, Smith GN. The effect of physical exercise strategies on weight loss in postpartum women: a systematic review and meta-analysis. Int J Obes 2014; 38(05):626-635

26 Catalano PM, Ehrenberg HM. The short- and long-term implications of maternal obesity on the mother and her offspring. BJOG 2006;113(10):1126-1133
27 Dennedy MC, Dunne F. The maternal and fetal impacts of obesity and gestational diabetes on pregnancy outcome. Best Pract Res Clin Endocrinol Metab 2010;24(04):573-589

28 Adamo KB, Ferraro ZM, Brett KE. Can we modify the intrauterine environment to halt the intergenerational cycle of obesity? Int J Environ Res Public Health 2012;9(04):1263-1307

29 Scifres C, Feghali M, Althouse AD, Caritis S, Catov J. Adverse outcomes and potential targets for intervention in gestational diabetes and obesity. Obstet Gynecol 2015;126(02):316-325

30 Wei YM, Yang HX, Zhu WW, et al. Risk of adverse pregnancy outcomes stratified for pre-pregnancy body mass index. J Matern Fetal Neonatal Med 2016;29(13):2205-2209

31 Deputy NP, Sharma AJ, Kim SY, Hinkle SN. Prevalence and characteristics associated with gestational weight gain adequacy. Obstet Gynecol 2015;125(04):773-781

32 Mathias PC, Elmhiri G, de Oliveira JC, et al. Maternal diet, bioactive molecules, and exercising as reprogramming tools of metabolic programming. Eur J Nutr 2014;53(03):711-722

33 Morales E, Groom A, Lawlor DA, Relton CL. DNA methylation signatures in cord blood associated with maternal gestational weight gain: results from the ALSPAC cohort. BMC Res Notes 2014;7:278

34 Ogden CL, Schoendorf KC, Kiely JL, Gillman MW. Fetal growth and childhood cholesterol levels in the United States. Paediatr Perinat Epidemiol 2008;22(01):5-11

35 Vinturache A, Moledina N, McDonald S, Slater D, Tough S. Prepregnancy Body Mass Index (BMI) and delivery outcomes in a Canadian population. BMC Pregnancy Childbirth 2014;14:422

36 Holowko N, Chaparro MP, Nilsson K, et al. Social inequality in prepregnancy BMI and gestational weight gain in the first and second pregnancy among women in Sweden. J Epidemiol Community Health 2015;69(12):1154-1161

37 Bahadoer S, Gaillard R, Felix JF, et al. Ethnic disparities in maternal obesity and weight gain during pregnancy. The Generation $\mathrm{R}$ Study. Eur J Obstet Gynecol Reprod Biol 2015;193:51-60

38 Truong YN, Yee LM, Caughey AB, Cheng YW. Weight gain in pregnancy: does the Institute of Medicine have it right? Am J Obstet Gynecol 2015;212(03):362.e1-362.e8

39 Brown MJ, Sinclair M, Liddle D, Hill AJ, Madden E, Stockdale J. A systematic review investigating healthy lifestyle interventions incorporating goal setting strategies for preventing excess gestational weight gain. PLoS One 2012;7(07):e39503

40 Chuang CH, Stengel MR, Hwang SW, Velott D, Kjerulff KH, Kraschnewski JL. Behaviours of overweight and obese women during pregnancy who achieve and exceed recommended gestational weight gain. Obes Res Clin Pract 2014;8(06):e577-e583

41 Kac G, Nucci LB, Spyrides MH, Duncan BB, Schmidt MI. Evaluation of the ability of a Latin-American gestational weight curve to predict adverse pregnancy outcomes. Int J Gynaecol Obstet 2009; 106(03):223-226

42 Padmanabhan U, Summerbell CD, Heslehurst N. A qualitative study exploring pregnant women's weight-related attitudes and beliefs in UK: the BLOOM study. BMC Pregnancy Childbirth 2015;15:99

43 Gilmore LA, Klempel-Donchenko M, Redman LM. Pregnancy as a window to future health: Excessive gestational weight gain and obesity. Semin Perinatol 2015;39(04):296-303

44 Willcox JC, Campbell KJ, McCarthy EA, et al. Gestational weight gain information: seeking and sources among pregnant women. BMC Pregnancy Childbirth 2015;15:164 